\title{
THE EFFORTS ON SUSTAINABILITY OF THE ACHIEVEMENT FKMP ON QS WORLD UNIVERSITY RANKING TOP 300 BY SUBJECT
}

\author{
N. F. Nasir ${ }^{*}$ and Y. Yusof \\ Centre for Energy and Industrial Environment Studies (CEIES), Faculty of Mechanical and Manufacturing Engineering, \\ Universiti Tun Hussein Onn Malaysia, 86400 Parit Raja, Batu Pahat, Johor, MALAYSIA
}

\begin{abstract}
This article review each vital elements and aspects that contribute to sustain recent achievement of Faculty of Mechanical and Manufacturing Engineering (FKMP), Universiti Tun Hussein Onn Malaysia by the QS world university ranking by subject in 2015. Some of recent and important issues are discussed and reviewed. The suggestions for improvements are also raised out for further reference.
\end{abstract}

Keywords: FKMP, efforts, world ranking, QS ranking

*E-mail address: fitriahnasir@gmail.com

\section{Introduction}

During searching a higher education opportunity, students need to be clear on their aims and select a quality higher institution to achieve their dreams. Therefore, QS Stars can be referred as it allows students to get a wider picture of an institution's qualities of its rating system. The QS rating system looks at everything from the employability of graduates, to sports facilities and community engagement. It is designed to reflect the mission of universities, and the needs of students who may be interested in things other than those to which traditional rankings are necessarily limited. In 2015, Faculty of Mechanical and Manufacturing Engineering (FKMP), from Universiti Tun Hussein Onn Malaysia has ranked at 251 in Asian University Rankings by subjects for year 2015 to 2016 [1]. The role of QS Stars audit is mainly evaluated an institution against over 50 different indicators. They award universities between one and five stars over eight wider fields, as well as an overall rating.

For the QS World University Rankings by Subject, the universities are ranked in individual subject areas, covering 36 subjects as of 2015. The rankings can useful for prospective students seeking to identify the world's leading schools in their chosen field of study. Three components will be observed and evaluated, which are academic reputation, employer reputation and research impact. The components are combined to produce the results in each subject, with weightings adapted by discipline [2].

\section{Academic Reputation}

The QS has carried out the global survey of academics since 2004. In 2015, the QS World University Rankings by Subject drew on responses from 85,062 academics worldwide. Having provided their name, contact details, job title and the institution where they are based, respondents identify the countries, regions and faculty areas they have most familiarity with, and up to two narrower subject disciplines in which they consider themselves expert. For each of the (up to five) faculty areas they identify, respondents are asked to list up to 10 domestic and 30 international institutions which they consider excellent for research in the given area. They are not able to select their own institution. For the QS World University Rankings by Subject, the results of the survey are filtered according to the narrow area of expertise identified by respondents. While academics can select up to two narrow areas of expertise, greater emphasis is placed on respondents who have identified with only one.

\subsection{Employer Reputation}

The QS World University Rankings are unique in incorporating employability as a key factor in the evaluation of international universities. In 2015, the QS World University Rankings by Subject drew on 41,910 survey responses from graduate employers worldwide.

The employer reputation survey works on a similar basis to the academic one, only without the channeling for different faculty areas. Employers are asked to identify up to 10 domestic and 30 international institutions they consider excellent for 
the recruitment of graduates. They are also asked to identify from which disciplines they prefer to recruit. After examining where these two questions intersect, they can infer a measure of excellence in a given discipline.

\subsection{Research Citations per Paper}

The QS World University Rankings by Subject measure citations per paper rather than per faculty member. A minimum publication threshold has been set for each subject to avoid potential anomalies stemming from small numbers of highly cited papers. Both the minimum publications threshold and the weighting applied to the citations indicator are adapted in order to best reflect prevalent publication and citation patterns in a given discipline.

All citations data is sourced from Scopus, the world's most comprehensive research citations database. Since 2013, a score based on 'h-index' has also been incorporated in the QS World University Rankings by Subject. The h-index is a way of measuring both the productivity and impact of the published work of a scientist or scholar. The index is based on the set of the scientist's most cited papers and the number of citations that $s / h e$ has received in other publications.

The h-index can also be applied to the productivity and impact of a group of scientists, such as a department or university or country, as well as a scholarly journal.

This article aims to review issues in sustaining the FKMP's recent achievement in QS World Ranking by subject. It also presents some recommendations for maintaining the excellent reputation.

\section{Recent Efforts and Issues}

Recently in 2013, the Ministry of Higher Education has developed a Malaysia Education Blueprint (Higher Education) (MEBHE) for a period of 10 years [3]. The blueprint presents current performance of the higher education in Malaysia, 5 system aspiration and student aspirations. It also outlined the Ministry of Higher Education's target of the next 10 years' time. According to the blueprint, it is projected about $70 \%$ of 2.5 million students will enroll in higher education institutions. The expanded aim of the will be quantified by the programs and available seats with close collaboration with industry as to ensure that supply matches demand.

To ensure the achievement of the system and student aspiration, the MEBHE has highlighted 10 shifts that address the key performance issues in the system, particularly with regard to quality and efficiency, as well as global trends that are disrupting the higher education landscape. The 10 shifts developed in the MEBHE are shown in Fig. 1.

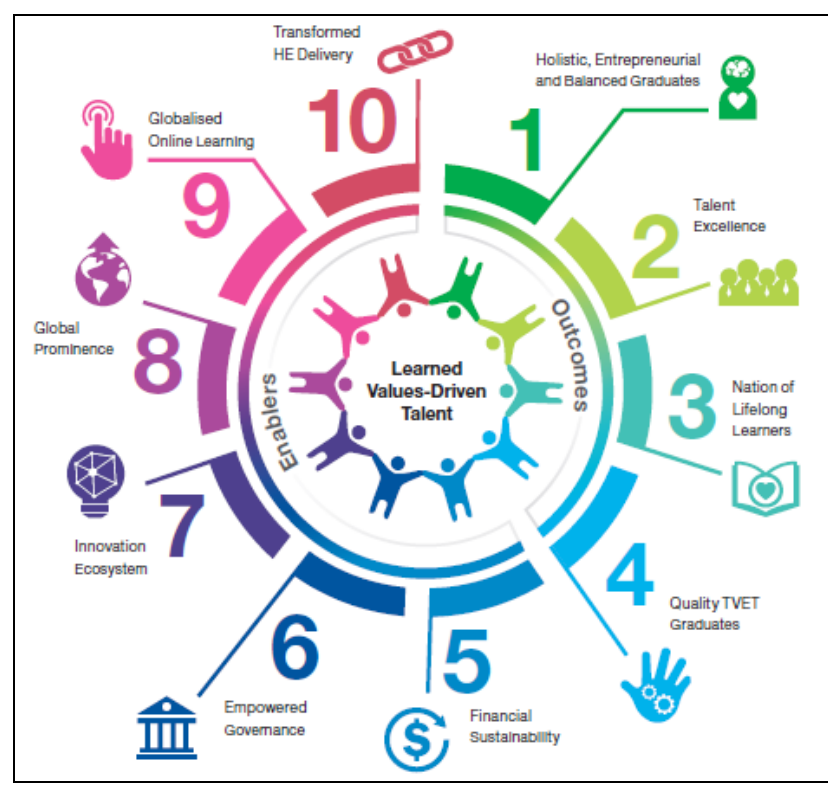

Fig. 1. Ten shifts of key performance issues

As Fig. 1 shows, the first four Shifts focus on outcomes for key stakeholders in the higher education system, including students in academic and TVET pathways, the academic community, as well as all Malaysians participating in lifelong learning. The other six Shifts focus on enablers for the higher education ecosystem, covering critical components such as funding, governance, innovation, internationalization, online learning, and delivery.

To sustain the achievement of FKMP in the ranking, it is necessary for all the FKMP team members to focus on the 10 Shifts outlined by the Ministry of Higher Education. However, some of issues are raised as below:

- The industry has reported that university graduates are lack of requisite knowledge, skills and attitudes.

- There is lack of specialization based on higher institutional strengths and focus areas.

- Malaysians have to move to Lifelong learning (LLL) so that the country can meet the changing skill needs of a high-income economy and maximizes the potential of individuals who are currently outside the workforce through reskilling and upskilling opportunities.

- Currently, our country requires the enrolment of TVET workers under the Economic Transformation Program (ETP). However, there is an undersupply of TVET workers in 10 of the 12 National Key Economic Area (NKEA) sectors. 
- The education cost will increase in future and students' expenditure cannot depends by government funded.

- The decision rights needs to move to one where the Ministry is focused primarily on its role as policymaker and regulator, and higher institutions $\mathrm{s}$ are empowered to steer their own journey of growth.

- Malaysia needs to integrate academia, industry, government, and local communities coming together in partnership for the incubation, development, and commercialization of ideas.

The issues may affect the performance of FKMP as well as it determine how the success of FKMP will look like in another 10 years. Therefore, extensive efforts can be performed to maintain the excellent performance in future years. Together with the 7 core business outlined by FKMP, Table 1 lists the focus of the efforts towards the more success of FKMP in future years.

Table 1. Efforts on sustainability of the achievement of FKMP on QS world ranking

\begin{tabular}{|c|c|c|}
\hline No & Effort & $\begin{array}{c}\text { Component's Focus of } \\
\text { QS Ranking by } \\
\text { Subject } \\
\end{array}$ \\
\hline \multirow[t]{5}{*}{1} & $\begin{array}{l}\text { Continue the } \\
\text { excellent teaching } \\
\text { and learning system } \\
\text { and environment. }\end{array}$ & Academic reputation \\
\hline & $\begin{array}{l}\text { Keep good } \\
\text { professional } \\
\text { relationship with the } \\
\text { student. }\end{array}$ & \\
\hline & $\begin{array}{l}\text { Give the students a } \\
\text { good knowledge that } \\
\text { is beneficial for their } \\
\text { future. }\end{array}$ & \\
\hline & $\begin{array}{l}\text { Provide service and } \\
\text { consultation for any } \\
\text { problem raised. }\end{array}$ & \\
\hline & $\begin{array}{l}\text { Provide the best } \\
\text { facilities to comfy the } \\
\text { students and } \\
\text { lecturers. }\end{array}$ & \\
\hline
\end{tabular}

\begin{tabular}{ll}
\hline 2 & Keep in touch with \\
industry as to match \\
the student's \\
reputation with \\
employer's \\
expectation. \\
Participation of all \\
students in any \\
graduate \\
employability \\
programs organized \\
by FKMP or UTHM. \\
Contribute ideas to \\
niche areas. \\
Increase the FKMP \\
Research Grants. \\
Share the excellent \\
profiles in Goggle \\
Scholar/ \\
LinkED/ORCID to \\
promote the FKMP \\
researchers. \\
Provide a good \\
research \\
environment.
\end{tabular}

As Table 1 shows, all the efforts require every one's commitments. It includes the dean, deputy deans, academic staffs, administration staff as well as supporting staffs. Excellency in future years can be achieved by FKMP by ensuring the core business (teaching and learning) is carried out effectively. One lecturer can vary their teaching style to suit the student's learning style [4,5]. Other than that, it is good to practice the student-centered approach [6] than teacher-centered-approach [7]. Another good effort to sustain the FKMP achievement is by building infrastructure \& technology needed to support the student-centered approach. For example, FKMP can establish a variety of eLearning site, virtual and open source learning forums. FKMP can also offer on-going training for staff who are uncomfortable with new technologies. Other than that, FKMP can provide study spaces (other than a traditional classroom) so that students can gather, share, discuss and assist one another [8].

It is also important to make sure the lecturers and students contribute to new knowledge by involving themselves in niche research areas. All the qualified FKMP staffs are encouraged to apply for research grants such as ERGS, MTUN, RAGS, UTP, GIPS and more. Afterwards, it is vital to show, promote and share their research profiles to the others, especially to the international level. If not, 
the research will not be acknowledged by other foreign researcher. This will help to increase the citation and $\mathrm{H}$ index of FKMP researchers. To ensure the FKMP students are matched with the industry expectation, it is important to shape their behavior during their learning time in FKMP. The professionalism and ethics need to be practiced along with the teaching and learning period as someone's personality can affect its good job performance [9 - 13].

\section{Conclusions}

The article discusses all the issues and efforts towards the sustainability of FKMP achievement on the QS world ranking by subject (Top 300). FKMP has achieved 251 rank which considered an excellent achievement since the first year it is established. It is vital for FKMP to focus on the three components outlined by the QS; academic reputation, employer reputation, and research citations per paper. If these elements can be implemented, it is hoped that the excellence can be more sustained and FKMP will be higher in the world ranking. It automatically increases the university level to be among of the top world universities.

\section{References}

[1] Limited, Q. Q. S. QS World University Rankings by Subject 2015 - Engineering Mechanical, Aeronautical \& Manufacturing. 2015 [cited 2015 2015/08/12]; Available from: http://www.topuniversities.com/universities/uni versiti-tun-hussein-onn-malaysiauthm/undergrad.

[2] Limited, Q. Q. S. QS World University Rankings by Subject: Methodology. 2015 [cited 2015 2015/08/12]; Available from: http://www.topuniversities.com/universityrankings-articles/university-subjectrankings/qs-world-university-rankings-subjectmethodology.

[3] Education, M.o. H. Malaysia Education Blueprint 2015-2025 (Higher Education). 2015.

[4] Mestre, L.S., 2 - Overview of learning style theories and learning style results from the Mestre study, in Designing Effective Library Tutorials, L.S. Mestre, Editor. 2012, Chandos Publishing. p. 19-31.

[5] Umar, I. N. \& Hassan, A. S. A. Malaysian Teachers' Levels of ICT Integration and Its Perceived Impact on Teaching and Learning. Procedia - Social and Behavioral Sciences 2015; 197: p. 2015-2021.

[6] Cornelius-White, Learner-Centered Instruction: Building Relationships for Student Success.
Thousand Oaks, CA: Sage; 2010.

[7] Nessipbayevaa, O. \& Eggerb, R. A Comparative Study of Teaching Style and Infrastructure of Learning of Higher Education in Austria and Kazakhstan. Procedia - Social and Behavioral Sciences 2015; 197: p. 1271 1277.

[8] Egizii, R. Self-directed learning, andragogy and the role of alumni as members of professional learning communities in the post-secondary environment. Procedia - Social and Behavioral Sciences 2015; 174: p. 1740 - 1749.

[9] Uppal, N., Mishra, S. K. \& Vohra, N. Prior Related Work Experience and Job Performance: Role of personality. International Journal of Selection and Assessment 2014; 22(1): p. 3951.

[10] Busato, V. V., et al. The relation between learning styles, the Big Five personality traits and achievement motivation in higher education. Personality and Individual Differences 1998; 26(1): p. 129-140.

[11] Busato, V. V., et al. Intellectual ability, learning style, personality, achievement motivation and academic success of psychology students in higher education. Personality and Individual Differences 2000; 29(6): p. 1057-1068.

[12] Chamorro-Premuzic, T. \& Furnham, A. Personality predicts academic performance: Evidence from two longitudinal university samples. Journal of Research in Personality 2003; 37: p. 319-338.

[13] Farsides, T. \& Woodfield, R. Individual differences and undergraduate academic success: the roles of personality, intelligence, and application. Personality and Individual Differences 2003; 34(7): p. 1225-1243. 